\title{
Progressive brain atrophy and white matter changes in MOG encephalomyelitis
}

Young Nam Kwon, MD, Jae Ho Jung, MD, PhD, Seong-Joon Kim, MD, PhD, Jung-Joon Sung, MD, PhD, and Sung-Min Kim, MD, PhD

Neurology ${ }^{\circledR}$ 2020;95:402-403. doi:10.1212/WNL.0000000000010403
Correspondence

Dr. S.-M. Kim

sueh916@gmail.com

Figure Serial brain MRI findings and clinical course in a patient with myelin oligodendrocyte glycoprotein encephalomyelitis with progressive disease course

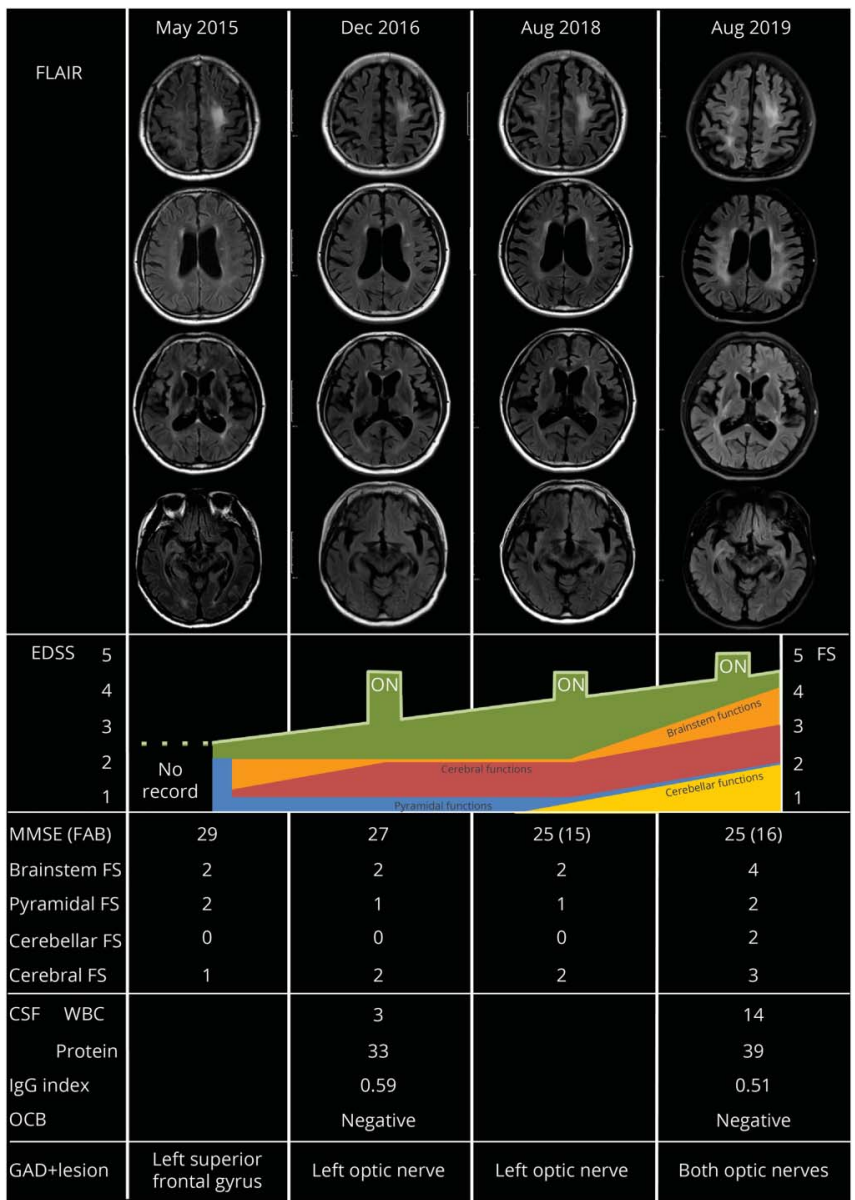

Brain MRI showed a T2 high signal intensity (HSI) lesion at the left frontal white matter, and also some multiple lesions involving periventricular white matter (PVWM) and juxtacortical area at first. Longitudinal follow-up brain MRI showed progressive brain atrophy combined with increased PVWM T2 HSI lesions. EDSS = Expanded Disability Status Scale; $F A B=$ frontal assessment battery; FLAIR = fluid-attenuated inversion recovery; FS = functional system score; GAD+ = gadolinium enhancement; IgG = immunoglobulin G; MMSE = Mini-Mental State Examination; OCB = oligoclonal band; $\mathrm{ON}=$ optic neuritis; $\mathrm{WBC}=$ white blood cell.

A 43-year-old man with a history of 7 repeated optic neuritis episodes since the 1990s developed dysarthria, dysphagia, and gait disturbance in 2015 with T2 high signal intensity (HSI) lesion in the left frontal white matter. He tested positive for myelin oligodendrocyte

From the Department of Neurology (Y.N.K., J.-J.S., S.-M.K.) and Departments of Ophthalmology (J.H.J., S.-J.K.) and Neurology (J.-J.S., S.-M.K.), College of Medicine, Seoul National University, Seoul National University Hospital; and Department of Neurology (Y.N.K.), The Catholic University of Korea, Eunpyeong St. Mary's Hospital, Korea.

Go to Neurology.org/N for full disclosures. Funding information and disclosures deemed relevant by the authors, if any, are provided at the end of the article. 
glycoprotein (MOG) antibody using cell-based assay, at a titer of $>1: 1,280$. ${ }^{1}$ During follow-up, longitudinal neurologic examinations revealed progressive neurologic deterioration without any acute aggravation of cognitive, cerebellar, motor, or sensory symptoms, despite treatment with corticosteroid, mycophenolate mofetil, and monthly IV immunoglobulin. ${ }^{2}$ His brain MRI revealed progressive brain atrophy combined with increased T2 HSI (figure) without any lesions in the spinal cord MRI. Progressive disease course with brain atrophy can be a manifestation of MOG encephalomyelitis.

\section{Acknowledgment}

This study was conducted according to the Declaration of Helsinki and was approved by the institutional review board of Seoul National University Hospital (IRB No. H-1902-0831010). The biospecimens and data used in this study were provided by the Biobank of Seoul National University Hospital, a member of Korea Biobank Network.

\section{Study funding}

This work was supported by grant 2019M3C7A1031776 from the National Research Foundation of Korea.

\section{Disclosure}

Y.N. Kwon, J.H. Jung, S.-J. Kim, and J.-J. Sung report no disclosures relevant to the manuscript. S.-M. Kim has lectured, consulted, and received honoraria from Bayer Schering Pharma, Genzyme, Merck Serono, and UCB; received a grant from the National Research Foundation of Korea and the Korea Health Industry Development Institute Research; and is an Associate Editor of the Journal of Clinical Neurology.
S.-M. Kim and Seoul National University Hospital have transferred the technology of flow cytometric AQP4-IgG and MOG-IgG assay to EONE Laboratory, Korea. Go to Neurology.org/N for full disclosures.

\begin{tabular}{lll} 
Appendix & Authors & \\
\hline Name & Location & Contribution \\
\hline $\begin{array}{l}\text { Young Nam } \\
\text { Kwon, MD, } \\
\text { MSc }\end{array}$ & $\begin{array}{l}\text { Seoul National } \\
\text { University } \\
\text { Hospital }\end{array}$ & $\begin{array}{l}\text { Drafting the manuscript, data } \\
\text { acquisition and analysis, read and } \\
\text { approved the final manuscript }\end{array}$ \\
\hline $\begin{array}{l}\text { Jae Ho Jung, } \\
\text { MD, PhD }\end{array}$ & $\begin{array}{l}\text { Seoul National } \\
\text { University } \\
\text { Hospital }\end{array}$ & $\begin{array}{l}\text { Data acquisition and analysis, read } \\
\text { and approved the final manuscript }\end{array}$ \\
\hline $\begin{array}{l}\text { Seong-Joon } \\
\text { Kim, MD, PhD }\end{array}$ & $\begin{array}{l}\text { Seoul National } \\
\text { University } \\
\text { Hospital }\end{array}$ & $\begin{array}{l}\text { Critical reading of the manuscript, } \\
\text { read and approved the final } \\
\text { manuscript }\end{array}$ \\
\hline $\begin{array}{l}\text { Jung-Joon } \\
\text { Sung, MD, } \\
\text { PhD }\end{array}$ & $\begin{array}{l}\text { Seoul National } \\
\text { University } \\
\text { Hospital }\end{array}$ & $\begin{array}{l}\text { Critical reading of the manuscript, } \\
\text { read and approved the final } \\
\text { manuscript }\end{array}$ \\
\hline $\begin{array}{l}\text { Sung-Min } \\
\text { Kim, MD, PhD }\end{array}$ & $\begin{array}{l}\text { Seoul National } \\
\text { University } \\
\text { Hospital }\end{array}$ & $\begin{array}{l}\text { Study conception and design, } \\
\text { drafting of the manuscript, data } \\
\text { acquisition and analysis, critical } \\
\text { reading of the manuscript, read and } \\
\text { approved the final manuscript }\end{array}$ \\
\hline & &
\end{tabular}

\section{References}

1. Lee H, Kim B, Waters P, et al. Chronic relapsing inflammatory optic neuropathy (CRION): a manifestation of myelin oligodendrocyte glycoprotein antibodies. J Neuroinflammation 2018; 15:302.

2. Lorscheider J, Buzzard K, Jokubaitis V, et al. Defining secondary progressive multiple sclerosis. Brain 2016;139:2395-2405.

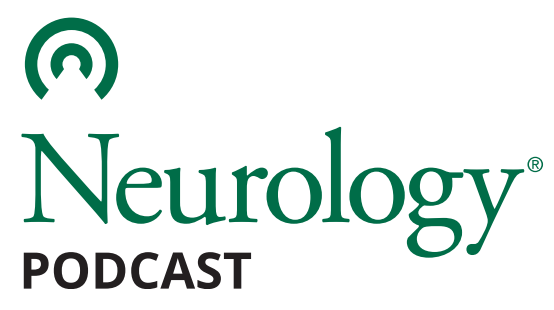

September 1, 2020

\section{Nine-year prospective efficacy and safety of brain-responsive neurostimulation for focal epilepsy (see p. 388)}

In the first segment, Dr. Halley Alexander and Dr. Martha Morrell talk about Dr. Morrell's paper discussing neurostimulation in focal epilepsy. Then, Dr. Dan Ackerman and Dr. Andrew Southerland continue their discussion on managing ischemic stroke, in the 3rd of a 4-part series.

Disclosures can be found at Neurology.org.

CME Opportunity: Listen to this week's Neurology Podcast and earn 0.5 AMA PRA Category 1 CME Credits ${ }^{\mathrm{TM}}$ by completing the online Podcast quiz. 


\section{Neurology}

Progressive brain atrophy and white matter changes in MOG encephalomyelitis

Young Nam Kwon, Jae Ho Jung, Seong-Joon Kim, et al.

Neurology 2020;95;402-403 Published Online before print July 20, 2020

DOI 10.1212/WNL.0000000000010403

This information is current as of July 20, 2020

Updated Information \&

Services

References

Subspecialty Collections

Permissions \& Licensing

Reprints including high resolution figures, can be found at: http://n.neurology.org/content/95/9/402.full

This article cites 2 articles, 0 of which you can access for free at: http://n.neurology.org/content/95/9/402.full\#ref-list-1

This article, along with others on similar topics, appears in the following collection(s):

All Demyelinating disease (CNS)

http://n.neurology.org/cgi/collection/all_demyelinating_disease_cns

Information about reproducing this article in parts (figures,tables) or in its entirety can be found online at:

http://www.neurology.org/about/about_the_journal\#permissions

Information about ordering reprints can be found online:

http://n.neurology.org/subscribers/advertise

Neurology ${ }^{\circledR}$ is the official journal of the American Academy of Neurology. Published continuously since 1951, it is now a weekly with 48 issues per year. Copyright @ 2020 American Academy of Neurology. All rights reserved. Print ISSN: 0028-3878. Online ISSN: 1526-632X.

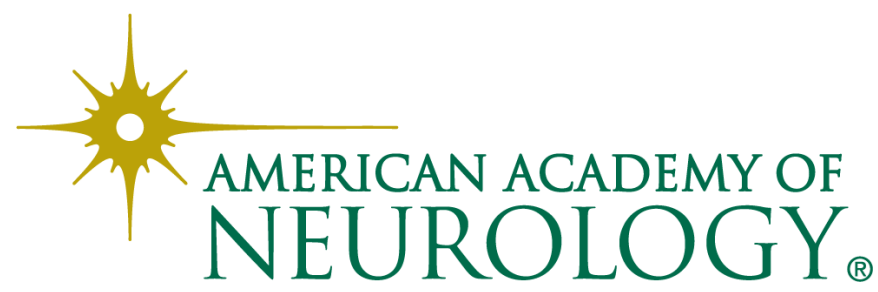

